\title{
PENGARUH KETINGGIAN PIER JEMBATAN TERHADAP PERILAKU KEDALAMAN JEPIT GROUP FONDASI TIANG BOR AKIBAT PUSHOVER ANALISIS
}

\author{
Basit Al Hanif \\ Prodi Teknik Sipil, Universitas Indonesia, Depok, Jawa Barat, 16424 \\ Email : albasit08@gmail.com
}

\begin{abstract}
ABSTRAK
Penelitian ini membahas perilaku respon tiang fondasi terhadap ketinggian pier akibat beban pushover analisis. Dalam penelitian ini dilakukan peninggian kolom pier dengan kekakuan (EI) tetap, dan peninggian kolom pier dengan memvariasikan nilai EI. Dengan variabel-variabel yang telah ditentukan, dilakukan analisis pushover pada struktur jembatan, dan dianalisis perilaku grup fondasi tiang bor akibat beban pushover. Penelitian ini menggunakan analisis nonlinear finite elemnet dengan menggunakan program Midas Civil guna menganalisis struktur jembatan dan program FB-Multipier guna analisis respon tiang fondasi. Dengan memepertahankan nilai EI pada tiap ketinggian, mendapatkan gaya geser dasar tiang pier mengecil pada setiap bertambahnya ketinggian. Sedangkan dengan melakukan variasi nilai kekakuan EI, mendapatkan gaya geser dasar yang relatif sama besarnya pada tiap-tiap ketinggian. Nilai kekakuan EI yang tetap, tidak memengaruhi nilai kedalaman jepit tiang. Sedangkan nilai variasi kekakuan EI, memengaruhi dari nilai kedalaman jepit tiang fodasi.
\end{abstract}

Kata kunci: Kekakuan, Ketinggian Pier Jembatan, Pushover analisis, Respon Tiang Fondasi

\begin{abstract}
This research discusses the behavior of pile foundation response to the pier height due to the pushover load analysis. In this study, the pier column was raised with fixed stiffness (EI), and by varying the EI value. By using the predetermined variables, a pushover analysis is carried out on the bridge structure, and the behavior of the bored pile group foundation is analyzed due to the pushover load. The Midas Civil Program is used to analyze the bridge structure and the FB-Multipier program is used to analyze the response of pile foundation. By maintaining the EI value at each height, the resulting pier pile base shear force decreases with each increase in height. Meanwhile, by varying the EI stiffness value, the base shear force is relatively equal at each height. The fixed value of the EI stiffness, does not affect the value of the depth of fixity. Meanwhile, a varied value of EI stiffness affects the depth of fixity of the pile foundation.
\end{abstract}

Keywords: Analysis pushover, Bridge's pier height, Foundation response, Stiffnes

\section{PENDAHULUAN}

Untuk Pembangunan jembatan Sungai Tondano merupakan salah satu bagian dari proyek pembangunan daerah di Kota Manado, Sulawesi Utara. Pembangunan jembatan ini menghubungkan dua daerah yang terpisahkan oleh Sungai Tondano. Panjang jembatan total sebesar 450 meter, tinggi 40 meter, dan lebar 34.1 meter.
Struktur utama jembatan bentang utama Pre-cast Tee Bulb, dengan jenis pondasi yang digunakan adalah pondasi borepile dengan diameter mencapai 1,5 $\mathrm{m}$ dengan kedalaman pile $48 \mathrm{~m}$.

Secara umum konstruksi struktur jembatan terbagi menjadi dua yaitu konstruksi bangunan atas dan konstruksi bangunan bawah. Konstruksi bangunan atas terdiri 
dari lantai kendaraan, bealok girder, diafragma, pier jembatan dan abutmen. Sedangkan konstruksi bangunan bawah terdiri atas pile cap dan tiang fondasi.

Dalam perhitungan kapasitas lateral tiang berdasarkan methode Broms, selain dibutuhkan parameter momen lentur, kuat geser tanah serta dimensi tiang (diameter dan kedalaman tiang fondasi) diperlukan pula titik jepit tiang dan kondisi ikatan kepala tiang fondasi (tiang ujung jepit dan tiang ujung bebas). Kedalaman titik jepit tiang fondasi umumnya diambil dengan nilai pendekatan adalah 1,5 m untuk tanah granular atau lempung kaku, sedangkan untuk tanah lempung lunak dan lanau digunakan nilai pendekatan adalah 3 kali diameter tiang.

Pada nilai pendekatan-pendekatan yang umum digunakan, perlu diteliti terkait nilai pendekatan tersebut terhadap ketinggian pier jembatan. Guna mendapatkan nilai pendekatan tersebut terhadap fondasi, maka perlunya melakukan analisis struktur atas dengan baik, guna mendapatkan nilai keluaran yang sesuai dengan perilaku kondidi nyata. Dengan berbagai macam metode untuk mengnalisis jembatan, pada penelitian ini dilakukan dengan pemilihan metode pushover untuk menganalisis struktur jembatan. Maka pada penulis mencoba mempelajari, dan menganalisa perilaku group fondasi tiang bor terhadap variasi ketinggian pier jembatan akibat metode pushover.

Tujuan dari penelitian ini adalah melakukan studi analisis kedalaman jepit tiang fondasi terhadap variasi berbagai ketinggian pier, akibat analisis pushover pada fondasi group tiang bor.

\section{Analisa Pushover}

Analisa pushover dilakukan dengan cara memberikan suatu pola beban lateral statik pada struktur, yang kemudian secara bertahap ditingkatkan dengan faktor pengali hingga target perpindahan tercapai. Analisa pushover menghasilkan kurva hubungan antara gaya geser dasar (base shear) dan perpindahan titik acuan. Pada Gambar dibawah ini dapat dilihat kurva hubungan antara gaya geser dasar dan peralihan akibat dari analisis pushover. Kurva kapasitas memberikan data bahwa terdapat kondisi linier sebelum mencapai kondisi leleh dan selanjutnya kondisi nonlinier.

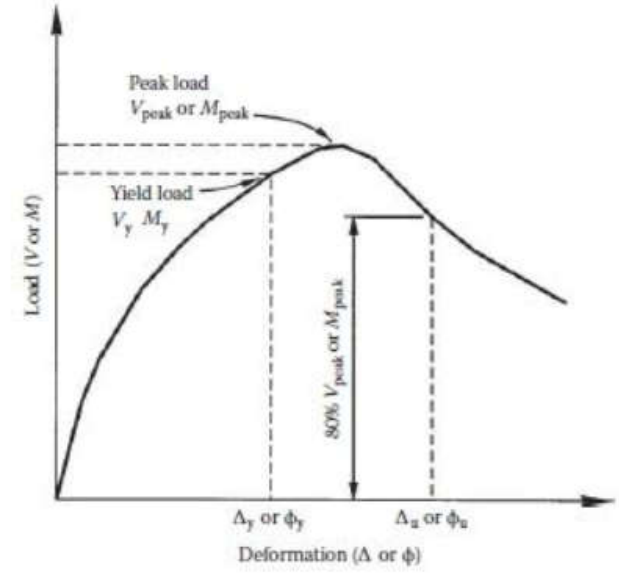

Gambar 1. Kurva Hubungan Gaya Lateral dan displacement (Hakim, 2014)

Tujuan dari analisa pushover adalah guna mendapatkan perkiraan dari gaya maksimum dan deformasi maksimum yang dimiliki oleh suatu struktur serta menetukan bagain dari struktur untuk dijadikan area kritis, sehingga dapat dilakukan perbaikan ketika struktur mengalami kerusakan.

\section{Metoda Spektrum Kapasitas}

Dalam Metode ATC-40, Spektrum Kapasitas, proses dimulai dengan menghasilkan kurva hubungan gaya perpindahan yang memperhitungkan kondisi inelastis struktur yang hasilnya diplot-kan dalam format ADRS (acceleration displacement response spectrum)

Format tersebut adalah konversi sederhana dari kurva hubungan gaya geser dasar dengan perpindahan lateral titik kontrol dengan menggunakan properti dinamis sistem dan hasilnya disebut sebagai kurva kapasitas struktur. Gerakan tanah gempa juga dikonversi ke format ADRS. Hal itu menyebabkan kurva kapasitas dapat diplot-kan pada sumbu yang sama sebagai 
gaya gempa perlu. Pada format tersebut waktu getar ditunjukkan sebagai garis radial dari titik pusat sumbu.

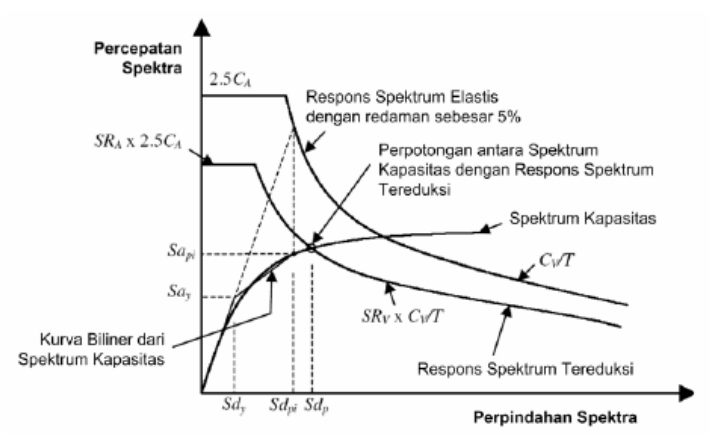

Gambar 2. Penentuan titik kinerja berdasarkan metode spektrum kapasitas (Hakim, 2014)

\section{Taraf Kinerja}

Taraf kinerja adalah keadaan atau tingkat kerusakan yang terjadi pada suatu bangunan bila terjadi beban gema rencana. Taraf kinerja adalah kondisi batas maksimum kerusakan struktural maupun nonstruktural yang terjadi pada struktur akibat beban gempa rencana . Taraf kinerja dinyatakan sesuai kriteria tingkat kerusakan fisik yang terjadi, ancaman terhadap kerusakan jiwa manusia dan kemampuan layan struktur pasca gempa.

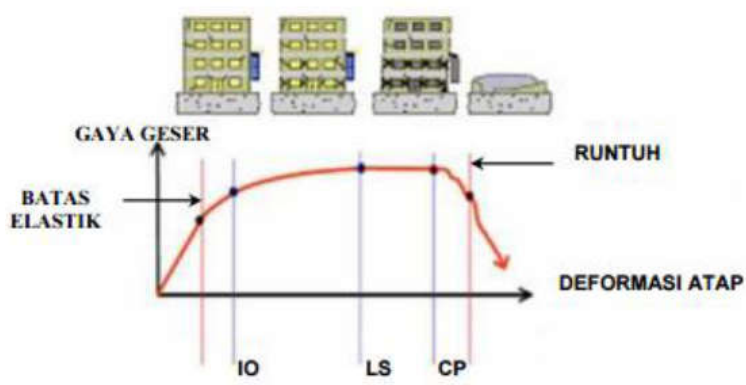

Gambar 3. Tingkat Kinerja Menurut FEMA 273 (Hakim, 2014)

\section{Fondasi Terkena Beban Lateral}

Dalam mendesain tiang fondasi yang menerima gaya aksial, lateral dan momen, harus memenuhi tiga kriteria sebagai berikut : Tekanan yang terjadi pada tanah tidak melebihi kapasitas ultimate dari yang mampu ditahan oleh tanah tersebut, defleksi yang terjadi tidak boleh melebihi dari kapasias yang diijinkan, dan Integritas struktural dari sistem pondasi harus terjamin mutunya.

Tiang fondasi selain direncanakan untuk menahan gaya aksial, juga harus mampu menahan gaya lateral yang terjadi, guna menghindari kegagalan akibat gaya lateral yang bekerja pada bangunan tersebut.

\section{P-Y Curve}

Dalam perhitungan nilai tekanan tanah ultimate dalam kondisi tekanan tanah lateral untuk interaksi tanah dengan struktur memerlukan suatu metoda khusus dalam perhitungannya. Masalah ini membutuhkan solusi sebuah masalah nonlinear dalam interaksi tanah dan struktur. Untuk memberikan solusi dalam hubungan antara soil resistance (p) dengan defleksi tiang (y) maka py curve memberikan hubungan antara keduanya.

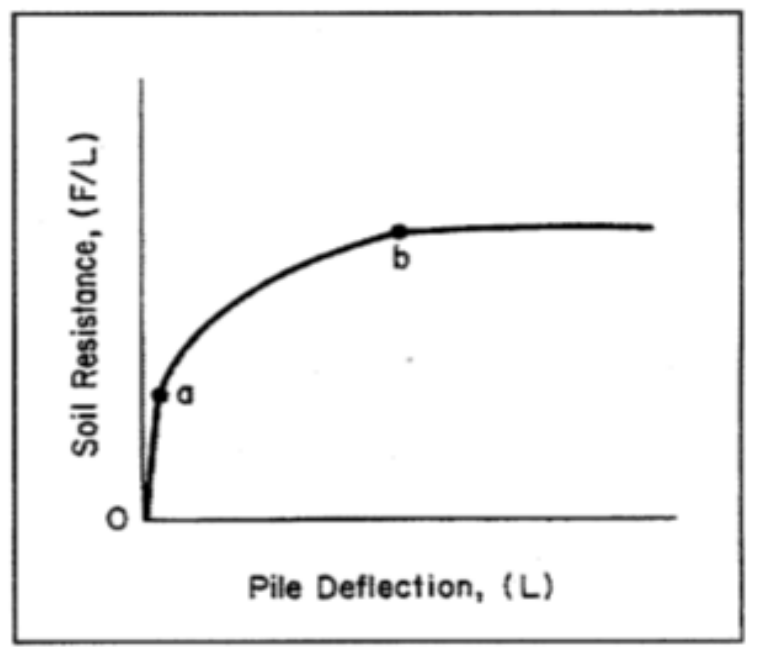

Gambar 4. konsep dasar kurva p-y Reese, 1997)

Pada kurva tersebut garis 0 -a memperlihatkan bagian dari tanah yang bersifat elastis pada defleksi yang kecil. Pada garis a-b merupakan bagian transisi dari kurva yang berbentuk non linier, dimana nilai soil resistance (p) pada poin b telah tercapai nilai ultimate dari soil resitance. Bagian horizontal pada kurva py diatas 
menujukan bahwa tanah bersifat plastis dengan tidak adanya kehilangan shear strength pada peningkatan strain.

Metode ini bersifat semi-empiris karena bentuk kurva p-y ditentukan dari uji beban lapangan. Reese (1977) telah mengembangkan sejumlah kurva empiris atau untuk tipe tanah yang tipikal berdasarkan hasil pengujiam lapangan pada tiang yang diinstrumentasi penuh. Untuk interaksi tanah - fondasi tiang maka digunakan persamaan sebagai berikut :

$$
\frac{P}{P_{u l t}}=0.5\left(\frac{y}{y_{50}}\right)^{1 / 3}
$$

Dimana :

$\mathrm{P} \quad=$ Resistensi lateral tanah

Pult = Resistensi lateral tanah (Np c D)

$\mathrm{Np}=$ Koefisien resistensi lateral tanah ultimit

c = kuat geser undrained

D = Diameter pie

$\mathrm{y} \quad=$ defleksi tiang

\section{P-Multiplier}

Pengukuran perpindahan dan tekanan dalam kelompok tiang pancang skala penuh dan sentrifugal menujukkan bahwa tiang dalam suatu kelompok tiang menerima beban lateral yang tidak sama. Tergantung pada lokasinya di dalam suatu kelompok tiang dan jarak antar tiang. Distribusi beban yang tidak merata diantara ini disebabkan oleh shadowing effect, dimana istilah tersebut digunakan untuk penjelasan overlapping dari zona kegagalan dan reduksi resistensi dari tanah.

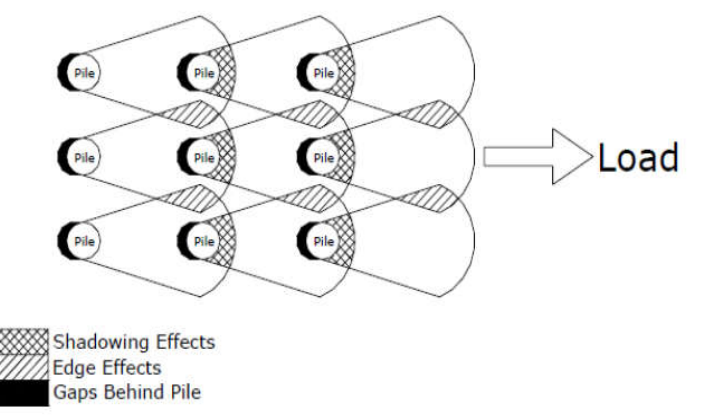

Gambar 5. Distribusi reduksi kapasitas lateral tiang dalam keompok tiang (Fayyazi, 2012)

Konsep P-multiplier (juga disebut faktor fm) dijelaskan oleh Brown et al (1988), sebagai cara untuk memeperhitungkan efek kelompok tiang dengan membuat kurva p-y.

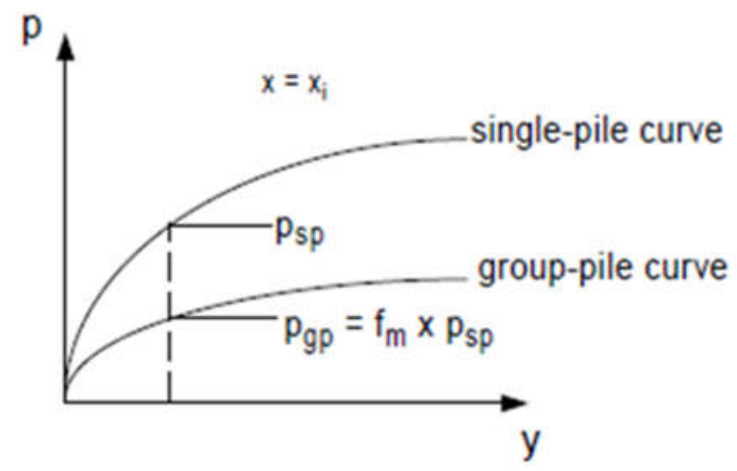

Gambar 6. Konsep P-multiplier untuk kelompok tiang (Mokwa \& Duncan, 1999)

\section{Tekuk Pada Tiang Fondasi}

Akibat beban struktur yang bekerja diatasnya, pondasi tiang tidak hanya menerima beban aksial dan momen, akan tetapi juga menerima oleh beban lateral yang bekerja. Ketika tiang menerima beban horizontal dan vertikal, tiang akan mengalami tekuk dan dianggap berperilaku terjepit pada kedalaman tertentu dibawah permukaan tanah. Titik kedalaman saat tiang jepit (zf), dimana momem maksimum dan kuat geser dari tiang $=0$.

Pondasi yang tertanam mungkin dibutuhkan untuk menahan beban vertikal ditambah dengan beban lateral dan bending moment pada ujung. Faktor k ekakuan R dan $\mathrm{T}$ merupakan persamaan yang telah ditemukan oleh Davinsson dan Robinson. 
Tiang yang tertanam memikul beban vertikal $\mathrm{P}$, horizontal $\mathrm{H}$, dan moment $\mathrm{M}$, saat setinggi e di atas permukaan tanah seperti pada gambar berikut.

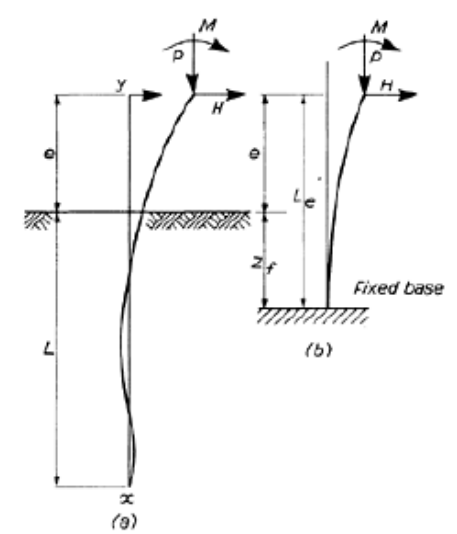

Gambar 7. Bending pada tiang akibat beban vertikal dan horizontal pada ujung kepala

(Davinsson, 1965)

Hetenyi (1946) merumuskan persamaan diferensial untuk kekakuan sebagai berikut:

$E I \frac{d^{4} y}{d x^{4}}+P \frac{d^{2} y}{d x^{2}}+K_{z} y=0$

Dimana,

EI = Kekauan dari tiang

$\mathrm{P}=$ Beban aksial

$\mathrm{k}=$ Modulus tanah

Terzaghi (1955), untuk tanah berkohesi yang mengalami over consolidated mempunyai nilai modulus tanah yang konstant pada setiap kedalaman pada gambar (a), dan untuk tanah yang memiliki modulus bertambah secara linear (b).



(a)



(b)
Gambar 8. variasi modulus subgrade terhadap kedalaman (a) pada tanah berkohesi over consolidated (b) pada tanah bergranular, lempung dan lanau pada kondisi normal (Davinsson, 1965)

Untuk tanah yang memiliki modulus konstan :

Depth to point of fixity, $\quad \mathrm{zf}=1.4 \mathrm{R}$

Untuk tanah yang memiliki modulus yang bertambah secara linear:

$\mathrm{zf}=1.8 \mathrm{~T}$

Dimana

$$
T=\left(\frac{E I}{n_{h}}\right)^{0.2}
$$

$$
R=\left(\frac{E I}{k_{h}}\right)^{0.25}
$$

Keterangan:

$\mathrm{E}=$ Modulus elastisitas $(\mathrm{kPa})$

$\mathrm{I}$ = Momen inersia dari penampang tiang

$\mathrm{kh}=$ modulus rekasi subgrade dari Terzaghi

$\mathrm{nh} \quad=$ nilai koefisien modulus variasi

\section{HASIL DAN PEMBAHASAN}

Pada penelitian ini struktur jembatan dimodelkan dengan peninggian pier jembatan secara bertahap, dengan variabel sebagai berikut :

1. Variasi ketinggian pier dilakukan dengan cara bertahap, dengan interval ketinggian adalah 5 meter.

2. Nilai kekakuan (EI) konstan pada tiaptiap ketinggian jembatan, dengan mempertahankan dimensi penampang pier sesuai dengan data perencanaan.

3. Memvariasikan nilai kekakuan (EI), dengan mengubah dimensi dari penampang pier pada tiap-tiap ketinggian. Acuan nilai EI adalah adalah sesuai dengan data perencanaan, dan mengacu pada gaya geser dasar pada ketinggian 40 meter. 


\section{Pushover Analisis Dengan Inersia Konstant}

Untuk analisis pushover, demand spectrum menggunakan nilai Ss dan S1 yang diperoleh dari peta gempa lokasi Manado dengan periode ulang 1000 tahun (7\% dalam 75 tahun).
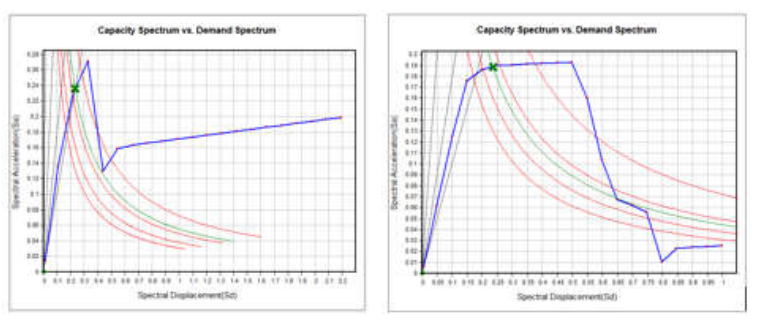

Gambar 9. Kurva kapasitas ketinggian pier 30 meter (a) arah - $\mathrm{x}$, (b) arah - y
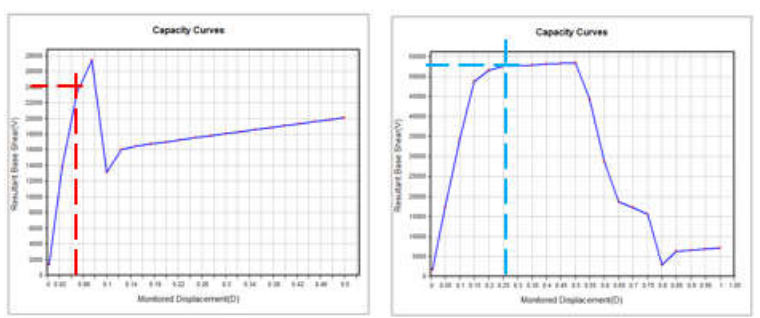

Gambar 10. Kurva pushover ketinggian pier 30 meter (a) arah x (b) arah y

Berdasarkan hasil pushover analisis pada tiap-tiap ketinggian kolom pier, diketahui bahwa semakin tinggi pier maka semakin menurun nilai gaya base shear yang diterima pada saat performance point (Fpp). Akibat dari turunnya nilai base shear ketika pier di tinggikan sehingga nilai reaksi perletakan pada tiap ketinggian tidak berubah signifkan, hal ini dibuktikan dari tabel berikut.
Tabel 1. Base shear dan displacement pada kondisi performance point

\begin{tabular}{|c|c|c|c|}
\hline \multirow{2}{*}{$\begin{array}{c}\text { Depth } \\
\text { (m) }\end{array}$} & \multirow{2}{*}{ Direction } & Fpp & $\Delta \mathrm{pp}$ \\
\cline { 3 - 4 } & & $(\mathrm{kN})$ & $(\mathrm{m})$ \\
\hline \hline \multirow{2}{*}{30} & Arah X & 23289.6 & 0.05 \\
\cline { 2 - 4 } & Arah Y & 52505.7 & 0.25 \\
\hline \multirow{2}{*}{35} & Arah X & 26388.3 & 0.12 \\
\cline { 2 - 4 } & Arah Y & 43522 & 0.30 \\
\hline \multirow{2}{*}{40} & Arah X & 26886 & 0.20 \\
\cline { 2 - 4 } & Arah Y & 36475 & 0.40 \\
\hline \multirow{2}{*}{45} & Arah X & 27611 & 0.30 \\
\cline { 2 - 4 } & Arah Y & 29616 & 0.48 \\
\hline \multirow{2}{*}{50} & Arah X & 27048 & 0.43 \\
\cline { 2 - 4 } & Arah Y & 28093 & 0.60 \\
\hline \multirow{2}{*}{55} & Arah X & 25876 & 0.50 \\
\cline { 2 - 4 } & Arah Y & 24994 & 0.60 \\
\hline \multirow{2}{*}{60} & Arah X & 25212 & 0.64 \\
\cline { 2 - 4 } & Arah Y & 22278 & 0.70 \\
\hline
\end{tabular}

Berikut adalah hasil analisis respon tiang fondasi, berdasarkan reaksi pada kolom pier.

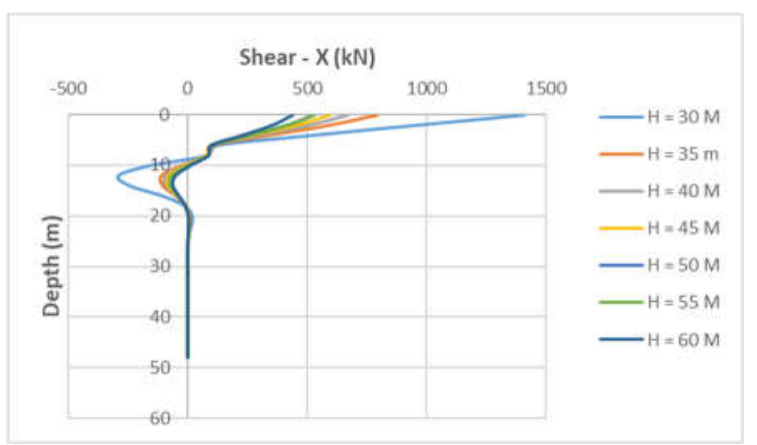

Gambar 11. Grafik gaya geser arah X

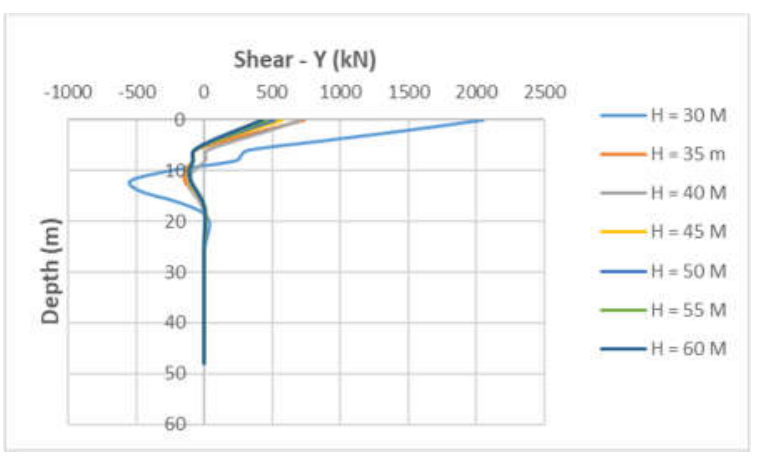

Gambar 12. Grafik gaya geser arah Y 


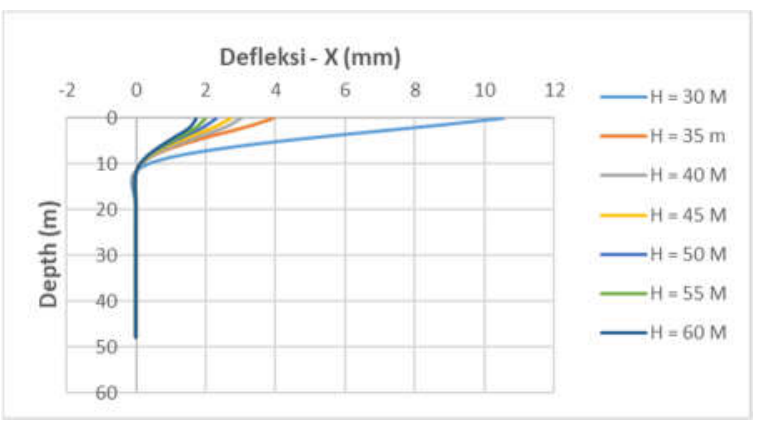

Gambar 13. Grafik Defleksi - X

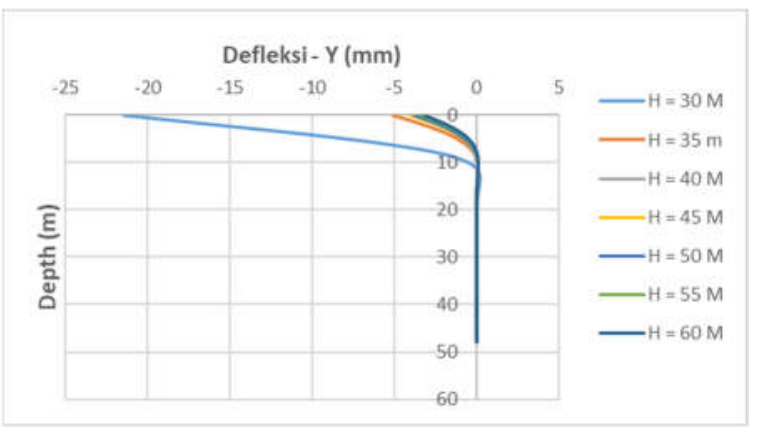

Gambar 14. Grafik Defleksi - Y

\section{Pushover Dengan Variasi Nilai Inersia}

Analisis pushover pada tahap ini yaitu adalah dengan memvariasikan nilai inersia penampang pada tiap-tiap ketinggian, guna mendapatkan nilai gaya geser dasar yang sama pada tiap ketinggian. Nilai ikekauan inersia dan gaya geser dasar pada kurva pushover mengacu pada kolom pier saat ketinggian 40 meter.

Tabel 2. Nilai EI pada ketinggian pier

\begin{tabular}{|c|c|c|c|c|c|}
\hline Tinggi & $\begin{array}{c}\text { Mutu } \\
\text { Beton }\end{array}$ & \multicolumn{3}{|c|}{ Profil Kolom Pier } & \multirow{2}{*}{$\begin{array}{c}\text { Rasio } \\
\text { EI }\end{array}$} \\
\hline \hline 40 & $\begin{array}{c}\text { F'c }^{\prime} \mathrm{m} \\
(\mathrm{Mpa})\end{array}$ & $\begin{array}{c}\text { B } \\
(\mathrm{m})\end{array}$ & $\begin{array}{c}\mathrm{H} \\
(\mathrm{m})\end{array}$ & $\begin{array}{c}\text { I } \\
(\mathrm{m} 4)\end{array}$ & \\
\hline 30 & 30 & 2.75 & 2.75 & 4.77 & 1.0 \\
\hline 50 & 30 & 2.30 & 2.30 & 2.33 & 0.5 \\
\hline 60 & 30 & 3.60 & 3.60 & 14.00 & 2.9 \\
\hline
\end{tabular}

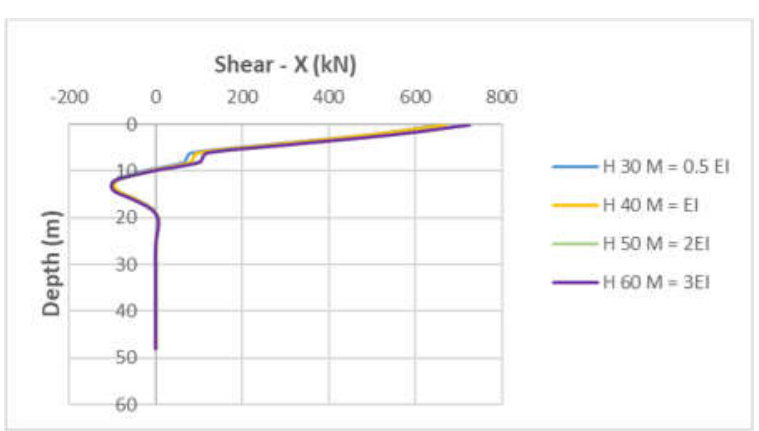

Gambar 15. Grafik gaya geser arah X

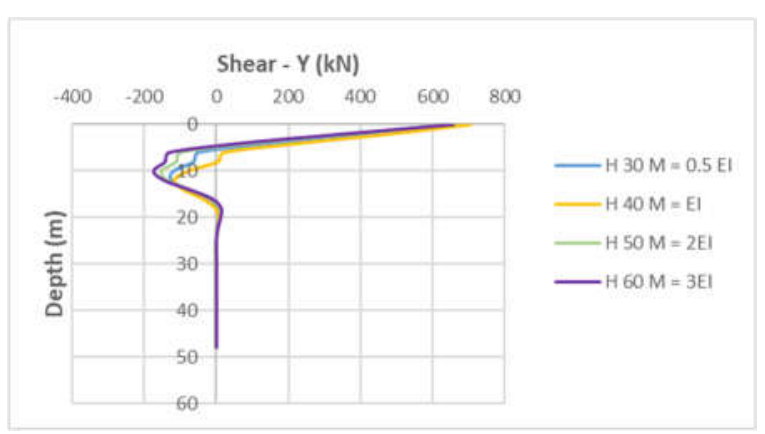

Gambar 16. Grafik gaya geser arah Y

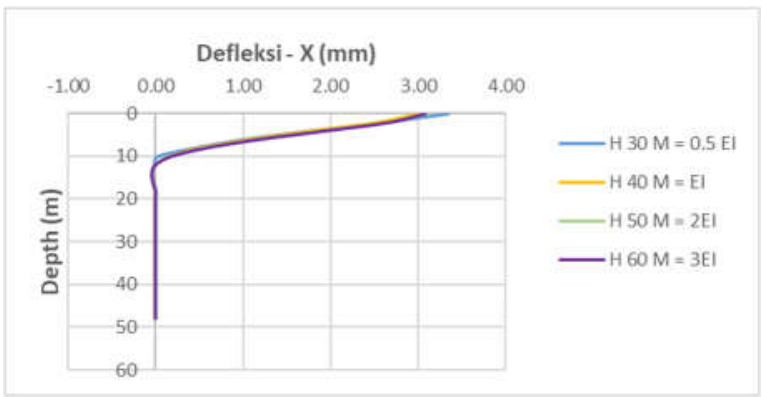

Gambar 17. Grafik defleksi arah X

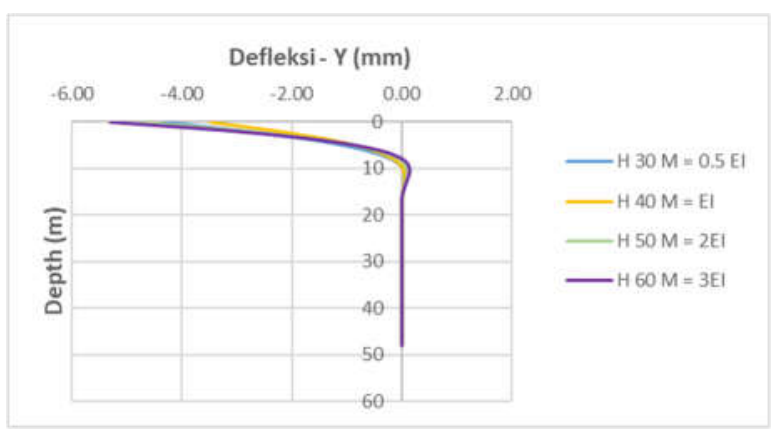

Gambar 18. Grafik defleksi arah Y 
Tabel 3. Kedalaman jepit tiang fondasi dengan variasi nilai inersia

\begin{tabular}{|c|c|c|c|c|c|c|c|c|}
\hline \multirow{3}{*}{ Depth } & \multicolumn{8}{|c|}{ Ketinggian Pier (m) } \\
\hline & \multicolumn{2}{|c|}{$30(0.5 \mathrm{EI})$} & \multicolumn{2}{|c|}{$40(\mathrm{EI})$} & \multicolumn{2}{|c|}{$50(2 \mathrm{EI})$} & \multicolumn{2}{|c|}{60 (3EI) } \\
\hline & $\begin{array}{c}\text { Lateral } \\
\text { X }\end{array}$ & $\begin{array}{c}\text { Lateral } \\
\text { Y }\end{array}$ & $\begin{array}{c}\text { Lateral } \\
\text { X }\end{array}$ & $\begin{array}{c}\text { Lateral } \\
\text { Y }\end{array}$ & $\begin{array}{c}\text { Lateral } \\
\text { X }\end{array}$ & $\begin{array}{c}\text { Lateral } \\
\text { Y }\end{array}$ & $\begin{array}{c}\text { Lateral } \\
\mathrm{X}\end{array}$ & $\begin{array}{c}\text { Lateral } \\
\text { Y }\end{array}$ \\
\hline$(\mathrm{m})$ & $(\mathrm{mm})$ & $(\mathrm{mm})$ & $(\mathrm{mm})$ & $(\mathrm{mm})$ & $(\mathrm{mm})$ & $(\mathrm{mm})$ & $(\mathrm{mm})$ & $(\mathrm{mm})$ \\
\hline 0 & 3.35 & -4.33 & 3 & -3.5 & 3.09 & -4.76 & 3.08 & -5.31 \\
\hline 2 & 2.62 & -2.78 & 2.53 & -2.24 & 2.68 & -2.8 & 2.67 & -3.01 \\
\hline 4 & 1.76 & -1.53 & 1.79 & -1.22 & 1.94 & -1.36 & 1.94 & -1.39 \\
\hline 6 & 1.01 & -0.68 & 1.08 & -0.54 & 1.19 & -0.48 & 1.19 & -0.43 \\
\hline 8 & 0.45 & -0.19 & 0.51 & -0.15 & 0.58 & -0.04 & 0.58 & 0.02 \\
\hline 10 & 0.02 & 0.02 & 0.16 & 0.02 & 0.18 & 0.1 & 0.18 & 0.14 \\
\hline 12 & -0.02 & 0.07 & 0 & 0.05 & 0 & 0.09 & 0 & 0.11 \\
\hline 14 & -0.04 & 0.04 & -0.04 & 0.03 & -0.04 & 0.04 & -0.04 & 0.05 \\
\hline 16 & -0.02 & 0.01 & -0.02 & 0.01 & -0.03 & 0.01 & -0.03 & 0 \\
\hline 18 & 0.00 & 0.00 & 0 & 0 & 0 & 0 & 0 & 0 \\
\hline 20 & 0.00 & 0.00 & 0 & 0 & 0 & 0 & 0 & 0 \\
\hline
\end{tabular}

Dari tabel 3 diketahui kedalaman jepit tiang fondasi pada ketinggian pier 30 meter, adalah pada kedalaman -10 meter. Sedangkan untuk ketinggian pier 40 dan 50 meter, titik jepit berada pada kedalaman 12 meter. Pier jembatan ketinggian 60 meter, titik jepit pada kedalaman -14 meter.

\section{KESIMPULAN}

Berdasarkan analisis pushover yang dilakukan pada pier dengan berbagai ketinggian pier jembatan terhadap perilaku group fondasi tiang bor, maka dapat ditarik kesimpulan sebagai berikut:

1. Gaya geser yang terjadi akibat variasi ketinggian dengan mempertahankan nilai kekakuan EI, mendapatkan gaya geser dasar tiang pier mengecil pada setiap bertambahnya ketinggian. Sedangkan dengan melakukan variasi nilai kekakuan EI, mendapatkan gaya geser dasar yang relatif sama besarnya pada tiap-tiap ketinggian.

2. Kedalaman jepit tiang fondasi pada berbagai variasi ketinggian pier jembatan dengan kekakuan EI yang tetap, tidak memengaruhi nilai kedalaman jepit tiang. Sedangkan pada variasi ketinggian dengan memvariasikan nilai kekakuan EI, memengaruhi dari nilai kedalaman jepit tiang fodasi.

\section{DAFTAR PUSTAKA}

[1] Budhu, M. (2011). Soil Mechanics and Foundations (3rd ed.). John Wiley \& Sons, Inc.

[2] Tomlinson, M.J. (1994). Pile Design and Construction Practice. E \& FN Spon. United Kingdom.

[3] Chopra AK, Gutierrez JA. (1974). Earthquake response analysis of

[4] R. L. Mokwa and J. M. Duncan, Investigation of The Resistance Of Pile Caps To Lateral Loading. Virginia Transportation Research Council, Virginia, 1999.

[5] Terzhagi, K. (1943). Theoretical Soil Mechanics. New York: John Wiley \& Sons, Inc.

[6] Reese, L. C., Isenhower, W. M. \& Wang, S.-T. (2006). Analysis and design of shallow and deep foundations. John Wiley \& Sons, Inc.

[7] Prakash, S. \& Sharma, H. D. (1990). Pile foundations in engineering practice. John Wiley \& Sons, Inc.

[8] Prasad, Y. V. S. N., dan Chari, T. R., (1999), Lateral capacity of model rigid piles in cohesionless soils, Soils Found., 39(2), 21-29.

[9] Lymon C, Reese,Jul 97. "Chapter 4 : Lateral Loads” EI 02C097. 
[10] Hakim, R. A., Alama, M. S. and Ashour, S. A. (2014) 'Seismic Assessment of RC Building According to ATC 40, FEMA 356 and FEMA 440', Arabian Journal for Science and Engineering, 39(11), pp. 7691-7699. doi: 10.1007/s13369014-1395-x.

[11] Davisson, M. and Robinson, K. (1965) 'Bending and buckling of partially embedded piles', 6th International Conference on Case Histories in Geotechnical EngineeringInternational Conference on Soil Mechanics and Foundation Engineering, pp. 243-246. Available at: http://trid.trb.org/view.aspx?id=122 242.

[12] Higgins, W., Martindale, H., Chakraborty, T., \& Basu, D. (2010) 'Assessment of the P-Y Method for Laterally Loaded Pile in Sand', Indian Geotechnical Conference, (1), pp. 833836.

[13] Hakim, R. A., Alama, M. S. A. and Ashour, S. A. (2014) 'Seismic Assessment of an RC Building Using Pushover Analysis', Engineering, Technology \& Applied Science Research, 4(3), pp. 631-635. doi: 10.48084/etasr.428.

[14] Kanakeswararao, T. and esh, B. G. (2017) 'Analysis of Pile Foundation Subjected to Lateral and Vertical Loads', International Journal of Engineering Trends and Technology, 46(2), pp. 113-127. doi: 10.14445/22315381/ijett-v46p219.

[15] Deng, T., Liu, Q. and Huang, M. (2017) 'Buckling of Fully Embedded Single Piles by Using the Modified Vlasov Foundation Model', International Journal of Structural Stability and Dynamics, 17(1), pp. 1-15. doi: 10.1142/S0219455417500079.

[16] Sajjad, F. M. et al. (2012) 'Evaluation of P-Multiplier Method for PerformanceBased Design of Pile Groups', Second International Conference on Performance-Based Design in
Earthquake Geotechnical Engineering, (11).

[17] Multistory buildings including foundation interaction. Earthquake Engineering Structure Dynamics;3:6577 
